\title{
TERROR: UM DISCURSO APÓS O 11 DE SETEMBRO ${ }^{l}$
}

\author{
Gayatri Chakravorty Spivak ${ }^{2}$
}

\begin{abstract}
Resumo
Este artigoéuma reflexão em buscade respostas diante das inquietaçõese da necessidade de explicar criticamente, por intermédio do conhecimento das humanidades, a guerra estadunidense contra o terrorismo. Apesar da impossibilidade de uma resposta à guerra, não podemos permanecer em silêncio. Assim, duas perguntas precisam ser formuladas: "Quais são algumas das respostas já existentes? E: como responder diante da impossibilidade de oferecer uma resposta?". A resposta da autora é orientada pelo entendimento de que "a cultura é sua própria explicação" e, a partir daí, ela exercita um olhar de aproximação com o "outro", para compreender tanto os "atentados suicidas" quanto a guerra contra o terrorismo. As reflexões da autora criticam as explicações estereotipadas formuladas pela direita e pela esquerda nos EUA. Questões de gênero, razão, religião e cultura permeiam sua análise que busca dar lugar às humanidades, às universidades e ao intelectual na tarefa de compreensão do "outro" para então ensaiar uma explicação sobre a guerra.
\end{abstract}

Palavras-chave: Terror. Humanidades. Secularismo. Cultura. Religião.

\footnotetext{
${ }^{1}$ Versão original publicada em Boundary 2, vol. 31, n. 2, de 2004, sob o título "Terror: A speech after 9-11”. Copyright (c) Gayatri Chakravorty Spivak. A Comissão Editorial agradece à autora por autorizar esta publicação. Tradução de Léa Tosold. Revisão Técnica de Silvana Mariano e Martha Ramírez-Gálvez.

${ }^{2}$ Professora da Columbia University, Estados Unidos. gcspiv@gmail.com
} 


\title{
TERROR: A SPEECH AFTER 9-11
}

\begin{abstract}
This article encloses a reflection in the search for responses in face of the anxiety and the necessity of critically explaining, with help of the knowledge of the humanities, the American war on terrorism. In spite of the impossibility of a one response to war, we cannot remain silent. Thus, two questions need to be formulated: "What are some already existing responses? And, how respond in face of the impossibility of response?". The response of the author is oriented by an understanding of "culture as its own explanations", from which she undertakes a training into imagining the perspective of the "other" in order to enable the understanding of both the suicide bomber and the war against terrorism. The considerations of the author criticize stereotyped explanations formulated by the right and the left in the USA. Questions concerning gender, reason, religion and culture permeate her analysis, which aims at opening a space for the humanities, the universities and the intellectual to fulfill the task of understanding the "other" and, therefore, of becoming able to delineate an account of the war.
\end{abstract}

Keywords: Terror. Humanities. Secularism. Culture. Religion.

\section{1}

s reflexões a seguir surgiram em resposta à guerra estadunidense contra o
terrorismo 3 . Inicio partindo da convicção de que não há resposta possível à
guerra. A guerra é uma caricatura cruel do que em nós parece servir como resposta. Não somos capazes de responder à guerra.

Contudo, não podemos permanecer em silêncio. A partir do imperativo ou da compulsão de falar, duas questões emergem: Quais são algumas das respostas já existentes? E: como responder diante da impossibilidade de oferecer uma resposta?

Ao atribuir a mim mesma, portanto, o poder [agency] de resposta, minha atestada qualificação institucional foi acionada. Sou uma professora de humanidades. Na sala de aula, dá-se início à formação para o que potencialmente produzirá o criticismo, capaz de sensibilizar uma esfera pública profundamente hostil à missão das humanidades entendidas como uma persistente tentativa de rearranjar desejos de maneira não coercitiva através do ensino da leitura. Antes de

\footnotetext{
${ }^{3}$ Uma primeira versão deste texto foi apresentada em conferência - "Responses to War" - da série Intervenções Feministas, organizada pelo Institute for Research on Women and Gender, da Columbia University, Nova York. Agradeço a Rosalind Carmel Morris pelo convite para participar na conferência.
} 
começar, distingo tal missão do acúmulo de descrições aparentemente políticas, tediosamente radicais e frequentemente narcisistas - de acordo com o que venha a ser tomado como a última tendência teórica euroamericana - transmitidas aos nossos estudantes em nome da crítica pública. Um rearranjo não coercitivo de desejos, então; essa repetida empreitada em sala de aula. Assim me vi construída como respondente.

Uma resposta não somente pressupõe e produz a construção de um sujeito de resposta: também constrói seu objeto. A que, afinal, respondem a maior parte dessas respostas?

A "guerra" ao Talibã, repetidamente declarada na mídia por representantes do governo dos Estados Unidos de diversos escalões a partir do presidente, foi simplesmente uma guerra em sentido genérico. Sem ter sido declarada por força de ato do Congresso, não poderia assumir propriamente tal nome. E, mesmo assim, não se tratou de uma resposta à guerra. Os detidos na baía de Guantánamo, tal como temos sido continuamente lembrados tanto pela direita quanto pela esquerda, não são prisioneiros de guerra nem podem ser tratados como tais de acordo com a Convenção de Genebra (a mesma não aplicável) porque, como diz entre outras coisas Donald Rumsfeld, "eles não lutaram com fardas" ${ }^{4}$. Os Estados Unidos estão lutando contra um inimigo abstrato: o terrorismo. Definições em manuais do governo ou documentos da $0 \mathrm{NU}$ pouco explicam o termo. A guerra é parte de um álibi que todo imperialismo confere a si mesmo, uma missão civilizatória levada ao extremo, como não poderia deixar de ser. É uma guerra ao terrorismo reduzida domesticamente a um processo, a um caso criminal: Estados Unidos versus Zacarias Moussaoui, também conhecido por "Shaqil" ou "Abu Khalid al Sahrawi", com 19 sequestradores mortos denominados não indiciáveis co-conspiradores no processo de acusação.

Aqui é onde posso começar: uma guerra reduzida a uma ação judicial e amplificada para fazer frente a uma abstração. Mesmo no nível mais genérico, essa oposição binária não pode seguir sendo sustentada. No entanto, com o objetivo de construir uma resposta, tal binarismo é útil. Recapitulando: reduz-se a um caso, amplifica-se a uma abstração. Não posso falar com propriedade a respeito da lei,

\footnotetext{
${ }^{4}$ Isso não é tão tolo quanto parece. Em uma interessante matéria em The American Prospect, Anne-Marie Slaughter também menciona esse dado como um motivo importante: "A convenção que rege prisioneiros de guerra define combatentes ilegais como participantes em conflitos armados que abusam de seu status civil a fim de ganhar vantagem militar: aqueles que não portam abertamente armas ou algum 'signo distintivo fixo', tal qual uma farda ou qualquer outra insígnia que os identificaria como soldados” (SLAUGHTER, 2002, p. 2).
} 
de casos. Não sou "responsável" ["responsible"] nessa área. Volto-me, então, para a abstração: terror-ismo.

Por ora, irei arriscar algumas palavras enquanto cidadã do mundo que aspira viver e prosperar sob "o princípio da legalidade". Quando acreditamos que punir perpetradores como criminosos é mais inteligente, ou até mesmo mais correto, que uma intervenção militar, não estamos necessariamente nos movendo rumo a uma paz duradoura. A não ser que nos proponhamos o exercício de imaginar o outro - uma tarefa necessária, impossível e indeterminada -, nada do que fizermos através do cálculo político-legal perdurará, mesmo assumindo o risco do "futuro anterior": algo que já terá sido ao planejarmos que será. Antes de requerer o surgimento de um tipo específico de "esfera pública" - corolário aos sistemas imperiais e ao trânsito de povos, a partir do momento em que diferentes "grupos" populacionais passaram a viver juntos -, esse exercício era parte da instrução cultural de maneira geral ${ }^{6}$. Posteriormente, tornou-se o particular ônus de uma faculdade institucionalizada de humanidades. Tenho em conta que estou suprimindo uma história toda aqui. 0 sujeito iluminado de Kant é um estudante de humanidades (KANT, 1996a). Em Critique of Power, Benjamin escreve: "o que se encontra fora da lei enquanto poder educativo em sua forma mais perfeita é uma das maneiras de expressão de poder divino" (BENJAMIN, 1978, p. 297).

Tive uma educação nos moldes europeus, mas não me restam dúvidas de que todas as instituições historicamente marcadas sobre a importância do momento educativo podem ser encontradas em qualquer sistema cultural. 0 que parece importante hoje, diante desse ataque sem precedentes ao templo do Império, não é apenas a intervenção não mediada por cálculos da esfera pública - a guerra ou a lei -, mas também o exercício (do poder educativo) que prepara para a irrupção do ético. Entendo o ético - e esta é uma posição derivativa - como uma interrupção do epistemológico que, por sua vez, é a tentativa de construir o outro como objeto do conhecimento. Construções epistemológicas pertencem ao domínio da lei, que aspira conhecer o outro, em cada caso particular, da forma mais completa possível e, assim, punir ou absolver racionalmente - razão, aqui, definida pelos limites propostos pela própria lei. 0 ético interrompe de maneira

\footnotetext{
${ }^{5}$ N. do T.: A autora faz aqui um trocadilho com a palavra "responsible" a fim de incluir na mesma expressão tanto o sentido de não ser capaz de oferecer uma "resposta" quanto o de não ser "responsável".

${ }^{6}$ Livy, em "History of Rome", vol. 1, p. 58-60, recordando a fundação da república romana, localiza isso no medo de Lucrécia de vir a ser representada como quem dormiu com um "homem de condição inferior".
} 
imperfeita esse processo a fim de ouvir o outro como a si mesmo, sem pretensão de punir ou absolver.

A crítica pública hoje deve insistir que não há quantidade de punição - seja legal, sobre indivíduos, seja militar e econômica, sobre Estados e populações, na verdade recompensas militares e econômicas, como um convite para a formação de alianças ou para fazer parte da Organização Mundial do Comércio - que possa levar a uma mudança duradoura, uma alteração epistêmica, por menor que seja. Temos também de observar e dar atenção ao preparo para o ético. E é justamente nisso que reside a responsabilidade pública das humanidades.

Em contraste, a "Guerra ao Terrorismo" acabou por gerar um intenso ressurgimento do nacionalismo, consolidado por um ato do Congresso: o Ato Patriota. Havia uma não contestada pressuposição dos intelectuais acadêmicos de que, pelo fato de o sistema econômico mundial agir multi e transnacionalmente, ou mesmo globalmente em seu mais alto grau, um consistente pós-nacionalismo ideológico forma a episteme contemporânea. Um enterro indecente foi dado a essa dose de pensamento irresponsável - uma consequência que, embora não planejada, não deixa de ser uma consequência.

Mulheres se destacam nessa guerra ao terrorismo, nessa monstruosa missão civilizatória. Não podemos ignorar as tão desembaraçadas e joviais mulheres, mostradas pela CNN, no comando de um porta-aviões. Uma delas, desconcertantemente jovem, disse aos espectadores: "Se eu posso dirigir um portaaviões, posso dirigir qualquer caminhão". 0 que veio em resposta ao mais bizarro e simplório [single-issue] exemplo de jargão feminista que tive a felicidade de ouvir da boca de um correspondente homem da CNN foi: "Ninguém mais vai poder fazer piadas sexistas sobre mulheres no volante". Todas as mulheres? As "mulheres do Afeganistão" são codificadas de maneira um pouco diferente.

Considerando a proeminência da questão de gênero, uma teoria crítica feminista tem de repetir que expandir infinitamente a guerra não irá necessariamente produzir uma justiça de gênero plural [multiple-issue] na esfera subalterna. As consequências mais visíveis, a exacerbação do terrorismo de Estado em Israel, na Malásia, na Índia e em outras partes do mundo, nada têm a ver com justiça de gênero. Arruinada, Cabul é uma "cidade internacional" de outra natureza que havia sonhado Abd-ur Rahman ao fim do século XIX, talvez com tropas de manutenção da paz da 0NU e acessos contínuos às versões globalizadas da cultura local estadunidense; algo compatível com as políticas de gênero dos EUA e da ONU irá surgir novamente como parte da consciência social (ABD AL- 
RĀHMĀN KHĀN, 1980) ${ }^{7}$. Mas esses grupos sensíveis às questões de gênero irão representar o subalterno tão pouco quanto, se não menos que, a Associação Revolucionária de Mulheres do Afeganistão (RAWA). Não há possibilidade, em um protetorado estadunidense, de gênero vir a sustentar a contínua e difícil mudança de curso do capital para o social, que é o melhor das lutas contra a globalização. Isso aconteceu durante a era dos "novos" movimentos sociais dos anos 1970 no que hoje chamamos de "sul global".

Algo tão difícil quanto a emancipação das mulheres pelos Estados Unidos é celebrado repetidamente na avaliação do regime soviético. Mulheres de classe média estão surgindo de onde estavam antes de haverem sido relegadas à clandestinidade pelo Talibã. Todos sabem que os EUA criaram o Talibã. De fato, nestes tempos de educação política instantânea para satisfazer a preferência da semana, esse é frequentemente o apogeu do conhecimento da esquerda liberal. Mas por que essas mulheres prosperavam como profissionais sob o regime soviético? Há uma singular ignorância acerca da história do desenvolvimento da intelligentsia afegã e seu genuíno envolvimento com a esquerda (MASSELL, 1974; MARWAT, 1997).

Existe uma linha interna de diferença cultural dentro de "uma mesma cultura". A emancipação das mulheres desde sempre seguiu tal linha, e essa história é maior que guerras, se é que qualquer coisa pode ser considerada assim. Comento a respeito em meu livro Other Asias ${ }^{8}$.

Outra resposta ao terror tem sido colocar o termo entre aspas - mercantilizálo, relexicalizá-lo [relexicalize it] para a história e a geografia, transformá-lo em peça de museu. Em seu viés ameno se encontra o marketing de um 11/09 sentimentalizado que é totalmente ofensivo. A isso se pode certamente agregar a crítica pública superficial e, no entanto, escrupulosa da indústria cultural visual.

\footnotetext{
7 A questão de "gênero", a abstração da diferença sexual, em si mesma discursiva por ser sempre postulada como uma diferença, tanto para os dominadores quanto para os subordinados, nunca está ausente de uma sociedade. Escrevo "novamente" porque, como digo no texto, a questão da justiça civil para mulheres pode ser traçada ao longo da história do desenvolvimento muitas vezes frustrado da intelligentsia afegã. Até onde eu saiba, essa história ainda não foi compilada. É possível começar a partir da perda do monopólio da Rota da Seda ou de Abd-ur Rahman.

${ }^{8}$ Spivak (2008). Comecei a traçar esse argumento em um texto intitulado "Gender", apresentado inicialmente no Department of Womens Studies, University of Pennsylvania (14 de novembro de 2001) e, posteriormente, na Hong Kong University (3 de junho de 2002) e na School of Oriental and African Studies, London University (20 de junho de 2002).
} 
Aí estão contidas metonímias das mais surpreendentes que negociam a área entre "duro" [hard] e "ameno" [soft]:

Por trás de um cercado vizinho protegido por uma lona e coberto com arame farpado [no Marco Zero] [...] estilhaços da antena de televisão suspensa, que marcava o ponto mais alto em Nova York - aproximadamente 528 metros de altura - repousam junto aos escombros perfurados que ainda restam da grande escultura esférica de bronze de Fritz Koenig, antigo marco central do World Trade Center na praça que ficava no andar térreo, interpretada como símbolo da paz mundial através do comércio. E protegido pela escultura de Koenig está [...] um aglomerado carbonizado e corroído de concreto implodido e aço fundido, móveis queimados e elementos pouco reconhecíveis, [...] um amontoado de ordem meteorític, que nenhuma força humana poderia haver forjado, mas que acabou de fato sendo criado pelo abrasador colapso das torres (LIPTON; GLANZ, 2002, p. 1).

Um objet trouvé, porque a "paz mundial através do comércio" é uma mentira. E as forças são humanas. 0 globo de Koenig - tido como o lápis-lazúli de Yeats ${ }^{9}$ - veio a ser instalado como memorial no Historic Battery Park, no Eisenhower Mall, próximo a Bowling Green e contíguo a Hope Garden. "The Sphere”, como é chamado, é lexicalizado no texto de Nova York como a capital do capital, na frase do imaginário que irá conter os significantes História (Eisenhower, Battery Park), Espaço (Battery Park, Bowling Green, Garden) e Esperança.

Próximo ao ocorrido, as banalidades conceituais se somavam ao que é, sem dúvidas, muito mais interessante em termos arquitetônicos - uma série de exposições, entre as quais escolhi por acaso uma intitulada "A New World Trade Center", na Max Protetch Gallery, em Nova York ${ }^{10}$. De um lado, o monumento mais perene - uma resposta ao tempo do terror pelo arranjo espacial, modelo clássico de escrita - blocos à moda Stonehenge marcam a posição exata do Sol durante os dois ataques em "Zero Zones", criado por Raymund Abraham. Do outro lado, a típica exortação pós-moderna ao esquecimento ativo: "Não consideremos nem mesmo a lembrança... Para quê?", oferecida pelos arquitetos do Foreign Office para suas torres em formato de cobra. Entre os dois, havia outras conceitualidades, incluindo uma crítica vagamente esquerdista das torres enquanto edifícios: "Abra mão do passado, de todas as maneiras já fora de sincronia (EUA=gigante, poder).

\footnotetext{
${ }^{9}$ N. do T.: Referência ao poema "Lapis Lazuli" (1936), de William Butler Yeats.

10 "A New World Trade Center: Design Proposals", Max Protetch Gallery, Nova York, de 17 de janeiro a 16 de fevereiro de 2002.
} 
Das ruínas das Torres emergirá a matéria generativa" (Thomas Mayne, Architects). A mais extravagante delas, as torres gêmeas de luz, que representam a inscrição das torres como numênica em vez de fenomênica, foi o monumento temporário escolhido pela cidade.

Entre todas essas respostas, considero a linha do meio-termo a mais alentadora. A Europa sempre foi boa em musealização. As aspas neutralizam, embora nesse caso uma arte muito politizada pode acabar alimentando as artes marciais, e a tarefa da responsabilidade nunca está encerrada. Tal resposta está agora envolvida, evidentemente, no conflito entre o concurso de esculturas, a Lower Manhattan Development Corporation e as convenções do luto.

Eu passo agora à minha segunda questão: que resposta dar diante da impossibilidade de resposta?

0 estereótipo de intelectual público, de Fareed Zakaria do Newsweek International até Christopher Hitchens, provocativo freelance inglês, poderia oferecer declarações que retratam a política estadunidense, vindo imediatamente à tona em resposta a qualquer sinal de crise. Tal atitudeé, sem dúvida, valorosa, requer frequentemente uma boa dose de coragem, mas não é uma resposta. Intensifica 0 carisma do intelectual e produz no leitor o sentimento de estar envolvido no calor dos acontecimentos. Esse tipo de mapeamento coletivo, fortemente dependente do trabalho de campo do jornalista investigativo vanguardista e de pobres compiladores de estatísticas, legitima contrariamente que o conhecimento é um fim em si mesmo ou, ainda, que há uma ligação direta entre conhecer e fazer política, seja enquanto direitos humanos ou teatro de rua.

Diferentemente, responder significa identificar-se com o outro, contemplar a possibilidade de cumplicidade - gerando, assim, a sensibilização que é baseada em "conhecer as coisas", ainda que superficialmente, a partir de sua complacência. A resposta pré-figura mudanças. Ao ler Aristóteles e Shelley, os alunos em geral perguntam: qual a diferença entre predição e pré-figuração? Negativamente, a diferença está na pretensa aparente falta de precisão do sujeito, na figura; positivamente, é o imenso alcance da figura no tempo e no espaço. A figura perturba a confiança no processo de tomada de consciência. Esse é 0 risco de uma resposta que espera estabelecer identificação através da figuração. Ao confinar nossa ideia do político exclusivamente ao controle cognitivo, não apenas evitamos o risco da resposta, mas também eliminamos totalmente qualquer possibilidade de resposta. Terminamos falando sozinhos ou com nossos clones no exterior. Conforme previsível tanto para a esquerda quanto para a direita, perde-se 
apoio quando se para de criar dicotomias entre o nós e o outro, quando se retira 0 oportunismo não questionador de si mesmo de fazer o bem ou de punir.

É para esse tipo de situação que Mahasweta Devi escreveu: "há pessoas para aprovar leis, há pessoas para dirigir jipes, mas ninguém para acender o fogo" (DEVI, 1995, p. 88). A resposta é o fogo. Você se queima se é tocado e chamado pelo outro. Caso algo que você lerá a seguir lhe afronte ou não the pareça suficientemente político, por favor, lembre-se disso.

A esquerda tradicional nos Estados Unidos e na Europa, em sua maioria, entendeu os eventos de 11/09 como uma batalha entre o fundamentalismo e 0 fracasso da democracia. Por ser indiana, costumo olhar mais a imprensa da Índia, na qual o tom da esquerda é menos exclusivista. "Dezenove homens árabes [...] levaram muitas de suas frustrações para dentro de quatro aviões comerciais", escreve Vijay Prashad, "o empobrecimento de outras linguagens de protesto social levou a que muitos jovens vestissem a camisa do islã a fim de articular sua alienação" (PRASHAD, 2002, p. 7-27). 0 tom utilizado por Prashad pode ser considerado como representativo da esquerda indiana.

Em contraste, Noam Chomsky pode ser lido como representante da linha de esquerda dominante nos EUA: “'globalização', 'imperialismo econômico' ou 'valores culturais' [são] questões completamente estranhas para Bin Laden e seus colaboradores e de nenhuma relevância para eles" (CHOMSKY, s/d). Se, por outro lado, pensarmos nos agentes envolvidos - estudantes politizados graduados -, diferentemente do estereótipo de Chomsky, não precisamos ocultar deles o dissabor de entender que, conforme os interesses dos poderosos se alteram, a Rússia e os EUA manobram para chegar juntos ao ouro negro do Cáspio passando por cima do Talibã, que florescia em 11 de setembro de 2001. Não havia qualquer chance de que suas cidades - citando um dos inúmeros boletins de programas e pesquisas do Banco Mundial, intitulado "Criando Cidades que Funcionam na Nova Economia Global" - pudessem participar "das mudanças [resultantes do comércio mundial que alcançou mais de 13 trilhões de dólares em 1998] que levam consigo a promessa de altos ganhos para os países em desenvolvimento, restando apenas a exposição a um risco ainda maior."(WORLD BANK, 1999).

Por que o islã não pode ser uma teologia da libertação para radicais da elite de classe média, quando uma grande cultura - chamada "islã" - continua sendo separada do curso em direção à modernidade? Não sou adepta da teologia da libertação. Sem sombra de dúvida, durante a melhor fase da teologia da libertação latino-americana, comprometida com a questão de gênero, eu teria insistido 
muitas vezes: "por que não podemos ter libertação sem teologia?". Porém, a possibilidade deve ser concedida se estamos tentando imaginar algo diferente do infeliz estereótipo.

Eu concordaria com o professor Chomsky que não é possível explicar a existência dos sequestradores exclusivamente pela globalização. Mas, eu também estaria de acordo com Vijay Prashad em que o 11/09, como o evento passou a ser denominado, não é apenas uma questão de religião. Não existe luto ou execução sem a imaginação do transcendental. E o transcendental, quando imaginado, tem nomes culturais. Mas há uma outra questão e, como vou argumentar na última parte, a ela não se deveria dar tão apressadamente o genérico nome de "religião". Também é verdade que uma confrontação milenar consta nos arquivos, desde que o islã saiu de seu tribalismo - a esse respeito eu, por haver tido uma educação europeia, conheço melhor o lado europeu da história. George W. Bush, se fosse letrado, poderia ter feito uso da Chanson de Roland. Foi sempre assim? Não tenho como saber. A cultura é sua própria explicação. Sayyid Qutb e Sheikh Ahmed Yassin tiraram proveito disso também.

Se essa intuição - de que a cultura é sua própria explicação - pode ser creditada, então ideias antropológicas de cultura e ideias marxistas de ideologia estão interligadas. Quando a palavra "muçulmanos" explica coisas em termos de "islã" e "americanos" em termos de "liberdade", começa-se, então, a gerar outro tipo de sentido. Por sua vez, a fragilidade de ambas as partes sob tensão pode, quem sabe, mover em direção ao entendimento. A narrativa impessoal da globalização - formação de capital produzindo, tanto quanto administrando, sua própria crise, explicada através da progressão Estado absolutista • colônia • imperialismo • império - passa, assim, a ser menos persuasiva que a explicação racional do $11 / 09^{11}$.

A explicação está antes contida na ideologia de pensar por si mesmo quais seriam os reais contornos do transcendental - tornando-o consequentemente "global" ou generalizável -em um sentido tanto histórico, quanto contemporâneo. Tomás de Aquino, separando Aristóteles de Ibn Rushd na Universidade de Paris, no século XIII, é um exemplo disso. A esse conceito ilusório, criado por si mesmo, desimpedido pela história e, no entanto, sensível às visíveis injustiças - militares, políticas e econômicas -se confere uma aparência de acesso, velocidade e momentaneidade por meio da internet, produzindo uma coletividade que vai se fortalecendo por meio de intensos laços afetivos masculinos, gerados pela

${ }^{11}$ Esse é, em linhas gerais, o argumento de Michael Hardt e Antonio Negri em Empire (2000). 
convivência conjunta entre estudantes, um fenômeno político bem conhecido por todos os educadores de ensino superior. 0 mesmo acontece com soldados, é claro, e guerrilhas - mas tenho mais fácil acesso ao fenômeno por parte de estudantes estrangeiros. É por esse caminho que estou tentando chegar nesses estranhos e jovens rapazes. Se o canal de notícias MSNBC estiver certo, a pessoa que pilotou 0 avião em direção à torre tinha 18 anos! Quando Terry Castle (2002) escreve com embaraço sobre sua obsessão por jovens soldados da Primeira Guerra Mundial, percebo o risco contido na tentativa que venho fazendo de buscar uma resposta verdadeira.

Sem dúvida, a imaginada confrontação milenar estava presente e havia sido comunicada entre os jovens rapazes que executaram o ataque e que jazem, esquecidos, entre as exaustivamente rememoradas 2.800 vítimas. No entanto, 0 senso comum nos diz que, uma vez havendo embarcado no plano, era o sonho em si mesmo que os encantava e a imaginária confrontação milenar teria se tornado a mais profunda das profundas motivações.

Esquecidos, sim. Mas quando, em maio de 2002, Nova York apresentou um memorial, tão europeu quanto militar no caráter espetacular ou visual de seus ritos de luto, não puderam deixar de receber os sete sequestradores que jazem naquele terreno por economia da natureza. Não existe apartheid no transcendental.

Irei agora citar boa parte do artigo "Profanação de Templos na Índia PréModerna", de Richard Eaton (2000), publicado em Frontline. Antes, no entanto, gostaria de mencionar um pequeno detalhe, porém importante, recordado por Syed Mujtaba Ali (1974) em seus manuscritos não publicados. Diz ele que há séculos pessoas da região afegã de Balkh foram à Índia aprender pársi em vez de ir ao Irã, e que a maior premissa do livro Asia Before Europe ${ }^{12}$ indicava que a orla do oceano Índico era motor muito mais importante de mudanças culturais, do que a atual forma de pensar em termos de "identidade nacional ou religiosa". Também é verdade que as relações entre o islã sul-asiático, o Irã e a Ásia Central eram historicamente fortes. Dessa maneira, mesmo que queiramos aceitar a consideração de Chomsky - de que eles não sabiam nada sobre a globalização -, podemos fazer referência a um imaginário cultural. Eaton (2000) escreve sobre "a eliminação de [...] autoridade política prévia", e continua: "[quando] tal autoridade era exercida por um monarca cuja própria legitimidade estava associada a um templo real, [...] aquele templo era normalmente saqueado, redefinido ou

${ }^{12}$ Syed Mujtaba Ali, Works, vol. 7. Kolkata: Mitra and Ghosh Publishers, 1974-. Chaudhuri (1990). 
destruído a fim de lograr o efeito de desassociar um derrocado [monarca] da mais proeminente manifestação de seu legado anterior. Templos não identificados dessa maneira, abandonados por suas autoridades reais, passaram a ser considerados politicamente irrelevantes e, geralmente, permaneceram sem danos".

"Seria errado", continua Eaton, "tentar explicar esse fenômeno apelando a uma essencializada 'teologia iconoclasta' aparentemente intrínseca à religião islâmica. [...] Ataques a imagens incentivados por inimigos dos reis têm sido, desde aproximadamente o século VI a.C., plenamente integrados ao [...] comportamento político [da região]. [...] Em resumo, desde aproximadamente o século VI, imagens e templos associados à autoridade dinástica passaram a ser considerados politicamente vulneráveis. (EATON, 2000, p. $64-65)^{13}$.

Não estou falando de deliberada escolha racional. Estou falando de um imaginário cultural produzindo "razão", um pouco como o arranjo em ritmo de parada militar do "Hino da Batalha da República" e o copioso uso dos afro-americanos no preâmbulo da declaração dessa "guerra" absolutamente catacrética. Sobre isso é possível fazer um paralelo entre a noção de dinastia e as linhagens de mobilidade de classe no contexto estadunidense. 0 que farei não será mais do que representar o confronto de setembro como a destruição de um templo - do comércio mundial e do poder militar - ao qual um Estado é associado. Talvez não seja uma mensagem referencial sobre a injustiça de uma ideologia do comércio e das armas como um todo, nem uma pretensa escolha racional. Ajudou que os edifícios eram altos, um fato não dissociado da representação de poder. É o que, certamente, está refletido do outro lado dos projetos à moda Stonehenge, como aquele que lança dois fachos de luz tão altos e estreitos quanto eram as torres, "faróis de luz como símbolo de firmeza", ou, ainda, aquele que visa construir uma World Art Tower como réplica exata da Torre Um, uma espécie de arca quadrilátera oca protegendo a que antes ocupava o espaço.

Se o outro lado precisa de um templo, este lado precisa ao menos de uma palavra: terror. Algo denominado "terror" é necessário a fim de que uma guerra possa ser declarada contra ele - uma guerra que se estende desde a supressão às liberdades civis, até os vagos argumentos de autopermissividade militar.

${ }^{13}$ Para compreender por que a distinção entre "Índia" e "Afeganistão" é, nesse contexto, artificial, cf. Lewis (1997, p. 213). Uma versão desse argumento foi publicada em The New Centennial Review. 
Sem a palavra terror, tal gama de coisas, justificada em nome das mulheres, não poderia ser legitimável.

Venho tentando acessar essa abstração - "terror" - a fim de imaginar algumas possibilidades. Ao longo dessa difícil tarefa, tem se tornado cada vez mais claro para mim que "terror" é o nome genericamente atribuído ao lado insolente dos movimentos sociais - ação coletiva extraestatal -, quando tais movimentos fazem uso de violência física. (Quando um Estado é denominado "Estado terrorista", a intenção implícita dessa designação é a de lhe retirar o status de Estado, de forma que, tecnicamente, entre para a categoria de "ação coletiva extraestatal". . ${ }^{14}$ "Terror" também é, claro, a designação de um afeto. Na arena política, "terror" enquanto movimento social e enquanto afeto caminham juntos para proporcionar um campo plausível de especulações psicológicas coletivas. Alega-se que os movimentos sociais possuem identidade psicológica. Em outras palavras, a prática do terror tanto civil quanto natural proporciona o fundamento para o exercício de diagnósticos psicológicos, o mais maligno ingrediente do racismo. Não tenho nem a competência, nem o gosto para tal exercício. Mas, devo ainda dizer que, no caso do "terror" - tendendo imperceptivelmente para o "terrorismo" - enquanto movimento social, o mundo talvez não passe de um antônimo para "guerra" - que nomeia a violência legítima, mas também, paradoxalmente, a paz. E neste ponto poderíamos divagar pelo labirinto no qual guerra e paz se tornam termos intercambiáveis, embora o status da guerra, enquanto agente, e o da paz, enquanto objeto, nunca oscile. Acabamos por aceitar o oxímoro: "forças de manutenção da paz".

0 Alto Comissariado das Nações Unidas para os Refugiados e a Save the Children - Reino Unido, em um informe de fevereiro de 2002, pediram que as missões de manutenção da paz parassem de exercer o tráfico de mulheres e de crianças. Feministas se mobilizam contra o predatório comportamento sexual dos "integrantes das forças de paz"15. 0 escândalo de estupros dentro do exército estadunidense é agora de conhecimento geral. Ao mesmo tempo, Barbara Crossette

\footnotetext{
${ }^{14} 0$ ex-secretário de Estado dos EUA Lawrence Eagleburger não sabia que os novos movimentos sociais estavam presentes na conferência "A América Tem Uma Missão Democrática?" ["Does America Have a Democratic Mission"], University of Virginia, 19-21 de março de 1998. A inútil definição de terror é citada em Chomsky (2001, p. 54). Derrida (2003) escreveu recentemente um livro dedicado inteiramente à possibilidade de Estados delinquentes.

${ }^{15}$ UNHCR e Save the Children Reino Unido, "Note for Implementing and Operational Partners on Sexual Violence and Exploitation: The Experience of Refugee Children in Guinea, Liberia and Sierra Leone", fevereiro de 2002.
} 
(2001, p. 3) propõe, segundo a opinião convencional, em artigo intitulado "Como Recompor uma Nação", que "exércitos que avançam com mais agilidade são necessários". Aqui se vê a típica divisão entre distintas esferas do discurso que, no entanto, atuam dentro do mesmo imaginário cultural, desta vez quase global: exércitos conquistadores violam mulheres.

Quando "terror" é um afeto, a linha entre agente e objeto oscila. Por um lado, o terrorista aterroriza uma comunidade, inunda seu dia a dia com terror. Mas também existe o sentido no qual o terrorista é tido como insensível ao terror, alguém que não sente o terror do terror e acabou se tornando diferente dos outros em virtude dessa transformação. Quando o soldado não tem medo de morrer, é corajoso. Quando o terrorista não tem medo de morrer, é covarde. 0 soldado mata, ou deve matar, certas pessoas. 0 terrorista mata, ou pode matar qualquer pessoa, indiscriminadamente.

No espaço entre terrorismo enquanto movimento social e terrorismo enquanto afeto, podemos declarar vitória. Liberdades civis, incluindo a liberdade intelectual, foram suprimidas e a permissividade militar, exacerbada; a identificação de suspeitos com base no perfil racial deturpou a comunidade política e uma cultura inteira se submeteu a isso como prevenção; desde o dia 28 de setembro de 2001 o Conselho de Segurança da ONU passou a adotar um amplo espectro de medidas antiterroristas. Apesar disso tudo, nós ainda somos capazes de transferir o registro para o afeto e dizer "não estamos sofrendo terrorismo, nós vencemos". E o velho tópos de intervir por causa das mulheres continua sendo usado. É para salvar as mulheres afegãs do terror que devemos manter a paz por força das armas. Quero distinguir o homem-bomba, o piloto camicase, desses típicos binários.

Com base na coação individual, ainda que deliberada, o "terror" suicida é, na excessiva destruição de templos dinásticos e na violação de mulheres, tenaz e poderosamente residual.

$$
* * * *
$$

Esses comentários sobre o suicídio terrorista provocaram tal grau de hostilidade que incluí aqui algumas palavras esclarecedoras que dediquei ao Dr. Michael Bernet em resposta a uma questão específica:

Acredito que o ensino responsável de bumanidades busca um rearranjo não coercivo de desejos no/a aluno/a. 
Uma extrema violação dessa responsabilidade é observada em grupos como Hamas ou Jihad Islâmica, que rearranjam coercivamente os desejos até que a coerção se pareça idêntica ao desejo de ser coagido. Eu, como muitos/as outros/as, acredito que a conduta desses grupos está ligada à política extremista do Estado de Israel. No entanto, deve-se admitir que esses grupos estão agora fora de controle, não menos porque não é possível reconbecer qualquer proposta de "paz" como confiável.

Aqueles cujos desejos são rearranjados de modo a se tornarem capazes de cometer um suicídio terrorista são invariavelmente jovens, cuja atitude em relação à vida épeculiarmente vulnerável a tal coerção.

Sou pacifista, não posso nem quero consentir com a violência, seja ela praticada pelo Estado ou por outros meios. Consequentemente, também acredito que a violência não pode ser extinta através de um implacável exterminio. Penso que temos de ser capazes de imaginar nosso oponente como um ser humano e procurar entender a significância de sua ação. É com base nessa crença - não a de ratificar o suicídio terrorista, senão a de encontrar o caminho para que ele possa vir a ter fim - que tentei imaginar qual mensagem tal ato poderia conter. Evidentemente, isso não significa que todo bomem-bomba tem justamente essas considerações em mente! Nesse ponto, também acredito que as coisas estão fora de controle e que uma geração foi completamente afetada. A minha geração, portanto, talvez seja vista como conselheira do desespero, mas certamente não como ratificadora da violência.

É conveniente para as leis da guerra distinguir entre civis e soldados. Isso é apenas para que se tenba lei, mas lei não é justiça. Sob a perspectiva da justiça e do discurso do ético, a vida humana não pode ser predestinada para a morte pelo direito positivo.

Com base na coação individual, ainda que deliberada, o "terror" suicida é, na excessiva destruição de templos dinásticos e na violação de mulheres, tenaz e poderosamente residual. Não tem a banalidade do mal. É fundamentado na estupidez de uma convicção levada ao extremo. Nós, que já não podemos mais morrer jovens, é que somos banais, ainda que seja a banalidade do meramente cotidiano. 0 sublime kantiano é - estritamente falando, e a partir do ponto de vista do espectador, para quem somente o sublime "é" sublime - estúpido. 0 sublime não tem sentido. Nós o colocamos sob algo como o controle porque "a vocação racional de nossa faculdade cognitiva” é acionada (KANT, 2000, p. 141) ${ }^{16}$.

${ }^{16} 0$ analítico do sublime vai da página 128 a 212. 
Se a partir do que estou dizendo agora você sente repugnância ou mesmo aversão, estará experimentando o risco inerente à resposta. Porém, isso não deve ser confundido com a estética efusiva de Stockhausen ${ }^{17}$. Legitimar o elevado número de mortes através do diagnóstico do "império do mal" também não é um bom caminho. Essa é igualmente uma forma de eliminar a possibilidade de resposta.

Não estou sugerindo que a violência ou o exercício do poder, tanto legítimo quanto ilegítimo, seja sublime no sentido coloquial. Para mim, a palavra "sublime" (mais que o termo alemão Erhabene, tal sua força na língua inglesa) foi para sempre marcada por Kant. Ela dá nome à estrutura: a coisa é muito grande para que eu a apreenda; estou assustado/a; a razão é então acionada pelo sistema imunológico da mente e me mostra, por implicação, que o que eu considerava grande não tem sentido, é "estúpido" da mesma maneira que uma pedra ou o corpo podem ser considerados estúpidos (Oxford English Dictionary, sentido 2). Eu chamo a grande coisa sem sentido de "sublime".

Não estou sugerindo que análises e resistências políticas e, em outro patamar, ajuda humanitária e direitos humanos sejam desnecessários. 0 que sugiro é que, se na imaginação não fizermos a tentativa de figurar o outro como um agente imaginativo, soluções políticas (e militares) não removerão o binário que levou ao problema em primeira instância. Para tanto, a instrução cultural está a serviço do exercício da imaginação.

Mesmo dentro da lógica dessa sugestão, não estou descrevendo todos os atos de 11 de setembro de 2001 como "sublimes" no sentido kantiano. Trata-se de um exercício imaginativo de experienciar o impossível - adentrar o espaço do outro -, sem o qual soluções políticas são fastidiosamente negligenciadas na perpetuação da violência. Parafraseando Devi, "há muitos oferecendo análises políticas e soluções, mas ninguém para acender o fogo". A instrução cultural através da imaginação em tempos de guerra é vista, no melhor dos cenários, como estetização e, no pior, como traição. Porém isso também é situacional.

0 atentado suicida - e, neste caso, os aviões eram bombas vivas - é uma autoaniquilação com propósito, um confronto do indivíduo consigo mesmo: 0 ponto extremo do autoerotismo, matando a si mesmo como um outro no processo de matar os outros. É quando uma pessoa vê a si mesma como objeto, capaz de destruição, em um mundo de objetos, de maneira que a destruição do outro não se distingue mais da destruição de si mesmo. 0 assustador é que a destruição do

${ }^{17}$ Foi amplamente noticiado que o compositor Karlheinz Stockhausen (2001), dias após o 11/09, fez menção ao ataque ao World Trade Center como uma obra de arte. 
templo real pode ser tomada como uma tarefa tão transcendental que meras vidas humanas se transformam em nada, tanto a dos outros quanto a minha. Esse é o momento que, a princípio, não se pode imaginar - mas é inútil fazer uso da palavra para encobrir novamente tal inaptidão. Não temos ideia se esses homens já haviam cometido assassinados anteriormente - eles não parecem diferentes de alunos estrangeiros em qualquer parte. Escutamos através das ligações telefônicas dos aviões que um deles cortou a garganta de um passageiro. É um detalhe horrível. Teria isso servido para conferir uma aura de morte a essa "loucura autorizada", não somente para pensá-la e fazê-la acontecer, mas para fingir ter controle sobre aquele peu profond ruisseau calomnié la mort? ${ }^{18}$

0 que quer que tenha sido, tal ato de confrontação global não caracterizou nem resistência nem algo multitudinário. Não existe algo que possa ser designado como morte coletiva. Não se pode punir, a despeito dos esforços tributados no processo judicial. Tampouco se pode relevar os acontecimentos enquanto resultado esperado da má política exterior dos EUA, como costumam geralmente tecer as análises políticas neste país. Esse gesto vai de encontro ao anseio destrutivo da mídia de "fazer luto" aos mortos com o máximo de sentimentalismo possível e, assim, tentar apreender o sublime do Marco Zero. Muitos de nós vimos ao vivo (se é que podemos usar tal palavra) o segundo avião chocar-se contra a segunda torre naquela manhã de 11/09. Esse encapsulado objeto, que cruzou velozmente e sem efeitos especiais o céu ensolarado, chocando-se contra a torre e explodindo em um enorme incêndio, encontra-se "além de Atea" - além "do limite do que a breve vida humana pode tão somente cruzar" (LACAN, 1992, p. 262-263).

Seu quase imperceptível avanço continha uma coleção de heterogêneos terrores pessoais, conectados tão desesperadamente à transcendentalidade que não podem ser compreendidos. Sou uma pacifista, não posso apoiar de maneira racional a violência. Mas temos de reconhecer o sublime do terror, mesmo sendo um nome inadequado para um afeto humano além do afeto, em vez de sair em busca de um novo termo que sirva para designar qualquer ato de violência não autorizada pelo Estado.

0 choque do segundo avião, visto an vivo, pode ser imaginado dentro da estrutura do sublime kantiano como um limite da faculdade imaginativa. No dia 21 de maio de 2002, no programa Late Show with David Letterman, Diane Sawyer continuou afirmando que "Charlie [Charles Gibson, o outro apresentador]

\footnotetext{
${ }^{18}$ N. do T.: Referência ao último verso do poema "Tombeau de Paul Verlaine”, de Stéphane Mallarmé - "um riacho pouco raso que calunia a morte".
} 
e eu negamos o ocorrido durante todo o tempo em que fizemos os comentários" - essa negação é, na estrutura descrita pelo analítico do sublime, o momento em que o sujeito sente "repugnância a partir da inadequação da imaginação" (KANT, 2000, p. 141).

Eu estava assistindo a esse canal no dia do atentado. Não me lembro da "negação" dos apresentadores, o que também se soma à lógica aqui descrita. Fazendo comentários sobre o monumento de 30 de maio de 2002, data da remoção da última coluna do World Trade Center que ainda havia permanecido de pé, Richard Meyer disse: "No momento em que vi o segundo avião, sabia que estávamos em guerra". Isso também pode ser interpretado como um momento dentro da estrutura de tentar lidar com o sublime. Trata-se da vontade moral em sua forma mais restrita: posso destruir a coisa que me assusta por força da resposta - a guerra é uma caricatura cruel do que em nós parece servir como resposta. Eu havia sugerido que 0 atentado suicida desfaz a diferença entre o homem-bomba e o seu inimigo. E também havia sugerido que, por trás da cortina de fumaça, o definitivo postulado do terrorismo passou a ser "uma violenta ação coletiva extraestatal", que desqualifica o próprio "Estado terrorista" da condição de Estado.

Ao passo que os Estados Unidos criam suas próprias regras na expansão da guerra contra o terrorismo, a permissividade para que "Estados terroristas" concentrem e legitimem suas políticas também se vê ampliada. Tenho em mente, claro, países como Israel e Índia, mas a chamada política de prevenção antiterrorista já atinge boa parte do globo. Seria descabido discorrer aqui acerca de considerações e análises dessa forma de terrorismo de Estado. Basta recordar 0 quão pouco me atraem os simplificados diagnósticos que acompanham momentos de crise. Para terminar, me restringirei, portanto, a comentar um ponto isolado em cada caso, todos relacionados à questão da crítica pública - 0 exercício para 0 ético nas humanidades.

Começo pela Palestina. Se o 11/09 foi executado por homens, na luta palestina contra Israel encontramos mulheres-bomba. Não penso que seja um fenômeno de gênero. A resistência suicida é uma mensagem inscrita no corpo quando já não se encontram outros meios. É ao mesmo tempo execução e luto, tanto para si mesmo como para o outro: você morre comigo pela mesma causa, não importa de que lado esteja, com a implicação de que não existe desonra nessa morte compartilhada. Somente os jovens podem ter seus desejos rearranjados tão drasticamente. Não alimento nenhuma simpatia pelos que os formam dessa maneira. Trata-se de um caso-limite de instrução cultural - 0 auge da coerção, 
do estímulo a determinadas escolhas, da imaginação representada como verdade revelada. E é justamente aí onde o diálogo deve começar - entre as humanidades exercitando o trivial deste lado e, do outro, seu extremo oposto. 0 que devemos questionar é a bistória dessa falha na instrução cultural, recodificada como triunfo, e não a instrução em si mesma. Pois essa história, que vem conduzindo a um apartheid e a uma violência que não se expressa em palavras no território deles, pode ser transformada em uma narrativa capaz de persuadir os jovens a morrer.

A mulher-bomba, uma vez persuadida, não coloca a si mesma uma questão de gênero. Compare-as àquelas combatentes mostradas pela CNN e você verá que não há registro de embates de gênero no atentado suicida. Quando baixar a poeira - no momento tão improvável que só parece ser possível quando toda Palestina já estiver em ruínas -, as distinções de gênero irão se assentar talvez sobre as mesmas linhas de antes ou outras similares. Bhubaneswari Bhaduri, a subalterna no livro Pode o Subalterno Falar?, foi uma mulher que usou seu corpo feminino para inscrever uma mensagem não ouvida; já a mulher-bomba que morreu com Rajiv Gandhi, não (SPIVAK, 1988). (É interessante que no imaginário masculino a mulher-bomba é marcada por gênero pela norma reprodutiva. Estou pensando no filme The Terrorist, de um indiano tâmil sobre Sri Lanka, e em The Cyclist, brilhante romance de Viken Berberian, uma corajosa tentativa de imaginar o mundo interior do terrorista suicida) ${ }^{19}$.

Ainda que eu esteja tentando imaginar o atentado suicida sem confiná-lo dentro da palavra "terror", que serve para designar qualquer coisa, a verdadeira lição que talvez se poderia extrair para os jovens potenciais suicidas é que a sua mensagem nunca será ouvida. Mesmo se um número assustador de crianças vier a se tornar terroristas suicidas, serão consideradas exceção, da mesma maneira que o suicídio é sempre uma morte excepcional - uma frase impossível. 0 que há de mais patético e poderoso a respeito de um atentado suicida é que, como a dança dos fantasmas, seu êxito consiste justamente em não haver êxito. Diante disso, a crítica pública pode apenas repetir, assumindo o risco de responder com a maior das banalidades: não vale a pena o risco.

Chego, por fim, à Índia. 0 conflito que saltou aos olhos do cotidiano, no contexto da guerra contra o terrorismo, durante o verão de 2002, foi Caxemira. Mas, se no caso palestino ninguém chegou a mencionar que a Cisjordânia é um

${ }_{19}$ The Terrorist, dirigido por Santosh Sivan, 1998; Viken Berberian, The cyclist. Nova York: Simon and Schuster, 2002. 
território ocupado, no caso da Índia o estado de Gujarat, onde a violência genocida contra cidadãos muçulmanos é tolerada pelo Estado e pela polícia, nunca chegou a receber devida atenção da cultura pública internacional. De fato, o jornal The Economist define os ataques hindus contra os muçulmanos em Gujarat como "certos, mas irrelevantes"20. Para fechar este tópico, gostaria de citar algumas palavras de um comovedor texto de Harsh Mander - ex-oficial do governo que renunciou após escrevê-lo -, que se encontra disponível na internet.

"Eu nunca ouvi falar de distúrbios que tivessem feito uso tão patente da subjugação da mulher enquanto instrumento de violência como na recémperpetrada barbárie de massas em Gujarat", escreve Mander (2002). Ele segue falando sobre o papel das leis:

Como alguém que atuou no Serviço Administrativo Indiano por mais de duas décadas, sinto enorme vergonha a respeito da abdicação dos deveres de meus pares na administração civil e policial. [...] A lei [...] requer que se aja de maneira independente, [...] imparcial, decisiva. [...] Se ao menos um/a oficial tivesse agido dessa maneira em Ahmedabad, poderia haver acionado as forças policiais e chamado o exército a fim de conter a violência e proteger as pessoas em questão de horas. Nenhum distúrbio se estende por mais que algumas horas sem a conivência ativa da polícia e da magistratura locais.

Este ensaio descreve a tarefa de longo prazo que subjaz tais necessárias e imediatas decisões. Ao fim de seu texto, Mander (2002) invoca o ético através de uma história:

Trago à memória a história dos distúrbios de Calcutá, quando Gandhi fazia greve de fome pela paz. Um hindu veio até ele a fim de contar a respeito de seu filho pequeno, que havia sido morto por uma horda de muçulmanos, e de sua profunda raiva e desejo de vingança. Assim se conta que Gandhi teria respondido: Se você realmente deseja superar sua dor, encontre um jovem [muçulmano], tão novo quanto seu filho, [...] cujos pais tenham sido mortos por uma horda de hindus. Crie esse menino da mesma maneira que você teria criado seu próprio filho, mas dentro da fé muçulmana na qual ele nasceu. Apenas então você encontrará o que pode curar sua dor, sua raiva e sua sede de vingança.

Se até então eu venho exortando as humanidades a exercitar a imaginação de maneira que a interrupção ética venha a prorrogar a tentativa de conhecer

${ }^{20}$ The Economist, 1 jun. 2002, p. 11 
o outro superficialmente - mesmo nos Estudos Culturais, ocupados com sua "própria cultura" -, aqui se inverte o jogo. Através da imaginação se deve acessar o que é oferecido como sendo a identidade do sujeito, mesmo quando todos os impulsos nos levam a repudiá-la. Não ajuda dizer, como os que são avessos ao fundamentalismo, que o verdadeiro hinduísmo não é assim; ou então exclamar: eu sou um secularista e não quero ter nada a ver com essas pessoas. A tarefa mais difícil é imaginar a mim mesmo/a como hindu - quando tudo que há dentro de mim resiste -, é entender o que em nós pode responder tão bestialmente - em vez de simplesmente apresentar um argumento ou impor regras que serão violadas em qualquer comunidade política que não constitua um Estado policial. Ao menos, estejamos preparados para isso através de um sustentável e não coercivo rearranjo dos desejos, que inclui movimentos aprendidos da cultura que nos ofende.

Enquanto as humanidades nos instruem a instruir, a teoria crítica distingue as discriminações de uma cultura global dominando nossa lamentável mentalidade local.

\section{2}

Na primavera de 2003, lecionei na University of Hawai i i-Manoa. Parte de meu trabalho consistia em oferecer aulas públicas. Eu havia proposto "0 Terror" antes de minha chegada. Por ocasião da aula, o Iraque havia entrado em colapso. A universidade estava profundamente politizada. Havia um pequeno grupo de estudantes havaianos e professores, bem como Pearl Harbor e a base militar - que um deles descreveu como "armas de destruição em massa na [ilha em forma de] Tartaruga". Um protesto comovente, pois a base militar foi uma das maiores empregadoras da classe baixa havaiana, um lugar que havia sido anexado à força pela chamada "Constituição da Baioneta", de $1887^{21}$. Eu não poderia refazer o script inicial, mas tentarei traçar o que estava em jogo nesta breve segunda parte do artigo.

Em meio ao que parecia ser um desastroso conflito com o Iraque, voltei a ler Beyond Vietnam, discurso proferido por Martin Luther King Jr. em 1967, na Riverside Church, em Nova York, localizada a apenas um minuto de onde vivo hoje. Volta e meia, no texto do discurso, Dr. King nos exorta a "falar por aqueles que foram designados nossos inimigos", porque "o espírito humano [não] se move sem enfrentar grandes dificuldades contra toda a apatia do pensamento

${ }^{21}$ Sobre a Constituição da Baioneta, cf. Osorio (2002). 
conformista que se encontra dentro do nosso íntimo e no mundo que nos cerca". "Como eles nos julgam?", pergunta King. "Quando perguntamos por que eles se recusam a negociar, devemos lembrar dessas coisas." Foi somente quando cheguei ao Havaí que consegui relacionar minha tentativa de imaginar o terrorista suicida com essas exortações. Foi lá que falei sobre o fato de que esse paralelo com 0 intento de Dr. King recebeu respostas hostis de várias pessoas e jornais e que isso era, em si, alarmante. Fiz referência ao discurso proferido na Ebenezer Baptist Church, em Atlanta, dia 30 de abril de 1967, que contém estas impressionantes palavras:

Não permita que alguém faça você acreditar que Deus escolheu a América como divina força messiânica para ser uma espécie de polícia do mundo. Deus tem Suas maneiras de se colocar perante as nações com juízo, e parece que posso ouvir Deus dizendo à América: "Você é muito arrogante! Se você não mudar suas práticas, irei me levantar e quebrar a espinha dorsal do seu poder".

Fico me perguntando - como enquanto repetia a justificativa dedicada ao Dr. Michael Bernet - se essas palavras poderiam ser aplicadas à supressão das liberdades civis, incluindo a liberdade intelectual, à exacerbação da permissividade militar, à deturpação da comunidade política através da identificação de suspeitos com base no perfil racial, bem como ao redesenho de uma cultura inteira para fins de prevenção da autoimunidade, da que falei na parte 1 deste artigo.

Apontei que estamos agora tão acostumados com a ideia de que é responsabilidade dos Estados Unidos, enquanto novo Império, policiar o mundo, que ficamos às voltas acerca de questões como contenção ou guerra, guerra pelo petróleo ou guerra justa, assassinatos ou mudança de regime, sempre tratados em oposição. Compartilhei com a audiência meus comentários, feitos ao então reitor da Columbia University, depois de escutar um excêntrico debate sobre o Iraque entre Alan Dershkowitz e George P. Fletcher.

Senti que não poderia formular apenas uma questão - até certo ponto a resposta não poderia vir a partir do que os debatedores apresentaram. Foi bastante perturbador escutar: "Às vezes é melhor fazer a coisa certa do que o que épermitido por lei". Isso, é claro, fundamenta a desobediência civil, mas justamente porque ela é civil. Não podemos falar de Estados operando dessa maneira. Quando estamos lidando com práticas estatais, isso se transforma em vigilância, justamente por não haver autoridade 
para "desobedecer". Fiquei também um pouco aflita quando vi mãos se levantarem na sala consentindo com o direito de "matar". Apenas uma mão levantada nesse sentido já seria preocupante - considerando que não estávamos falando de pena de morte, à que me oponho, mas que pelo menos pode ser discutida dentro do paradigma legal. Não é certo pensar que direitos "inalienáveis", por serem reiteradamente violados, não existem. A diferença entre estar em posse de mandados de tortura e um policial que por si mesmo decide que a tortura é legal, reside no fato de que este último pode ser punido se vir a ser descoberto! o problema em decidir a favor da legalização de assassinatos seletivos é certamente que, se um assassinato seletivo clandestino for descoberto, muito dificilmente poderá ser punido retroativamente, mesmo dentro de uma visão utópica do princípio legal. Foi perturbador observar como um debate que supostamente deveria tratar de nosso direito de invadir o Iraque acabou por se tornar uma afronta contra a Palestina. (Neste ponto teria preferido usar palavras mais fortes.) A reiterada condenação dos palestinos demonstrou falta de capacidade para imaginá-los em um contexto material em que Israel pudesse ter sido percebido como qualquer outra coisa que não "uma boa figura". É aqui que a ideia de George Fletcher (2002), em Romantics at War, de que o romantismo é simplesmente uma variedade de racionalismo, pode ser questionada. Devemos dizer que o copo está meio cheio em vez de meio vazio. 0 Romantismo foi uma descoberta da imaginação robusta - o que pode, em minha opinião, ser resumido nas palavras de Shelley (1967, p. 8), bem no contexto do início do capitalismo: "Nós queremos a faculdade criativa para imaginar o que sabemos". O grande legado do Romantismo foi a capacidade de imaginar o outro lado como um outro ser humano e não simplesmente como um inimigo a ser intimidado. O que eu dizia outro dia a respeito das humanidades vem agora ao caso, porque esse éo terreno onde uma base sólida nas humanidades nos permite pensar no espirito para além da letra da lei, bem como não pensar na imaginação como mera falta de razão. Embora acredite que Mike Davis, em seu livro Dead Cities (2002), tenha ido um pouco além dos limites, ele certamente tem uma boa dose de material documentado que não o permitiria pensar estarmos acima da lei por conta da ideia de que nunca seríamos irresponsáveis em relação ao uso de armas de destruição em massa. Isso sem falar no Agente Laranja! Admito que estou um pouco por fora dos fundamentos do debate porque a experiência bistórica me fez muito avessa à pré-suposição que se vê em ambos os lados, a saber, que os Estados Unidos deveriam pensar a si mesmos como detentores de um 
mandato imperial. Admito que a reiterada afirmação de George Fletcher, de que não há bons ou maus Estados, mas sim Estados iguais [equal], pode ser lida como um questionamento dessa pré-suposição".

Causou-me preocupação o fato de haver estudantes de mãos levantadas na faculdade de direito consentindo com os assassinatos, mesmo que sejam levados a cabo pelo Estado. Isso também é um coercivo rearranjo do desejo. Tal possibilidade faz necessário que evoquemos, mais uma vez, uma imaginação robusta a fim de desfazer a oposição binária entre o bom e o mau policial - lembrando que ambos são policiais. 0 impulso de ajudar impondo direitos humanos, dando coisas, dinheiro, mercantilizando a educação, ignorando a conscientização acerca das questões de gênero, está relacionado ao impulso de matar. Cito Kant (1996b, p. 78): "Embora [...] ainda possam existir boas ações dentro da lei, [se] [...] a atitude mental está [...] corrompida até a raiz [...], o ser humano é designado como mal". Hoje, em face do consentimento ao assassinato de Sheikh Yassin, a espinha dorsal da jurisprudência está quebrada.

Martin Luther King Jr. era cristão, "o campo de sua visão moral" era religioso e ele, por profissão, um pastor. Foi sua confiança no transcendental que lhe conferiu forças. Em "A Religião nos Limites da Simples Razão", Kant investiga se o secularismo é possível sem alguma intuição do transcendental que possa ser imposta racionalmente. Sua resposta é "não", porque a simples razão resiste por natureza à elaboração moral (Bearbeitung) (KANT, 1996b, p. 95), preferindo reparar um menos com um mais, impelir boas ações dentro da lei sem dar atenção às atitudes corruptas da mente.

Kant tem a coragem, nesse texto, de comparar a sanguinária violência aborígene à fria malícia do meio acadêmico. Dentro do paradigma da simples razão, ele não pôde se permitir passar do juízo determinante ao reflexivo, filosofar sem 0 aborígene como exemplo humano, como havia feito dois anos antes em sua Crítica da Faculdade do Juizo (SPIVAK, 1999, p. 26-29). Da mesma maneira, diríamos que as recompensas celestes - expressão que soa tão medieval em inglês (como tradutora tenho a competência para dizer algo a respeito) - que associamos com o "terror" islâmico podem ser comparadas à lógica calculista de atrair e empurrar - tal qual na história do cavalo que nunca alcança a cenoura pendurada com uma vara à sua frente -, através da qual a administração da paz e da guerra é levada a cabo pelos novos interesses imperialistas: aqui uma violação dos direitos humanos, ali uma sanção econômica, como se não fossem nada. Kant chama essa forma de acesso à salvação baseada em relação de trocas 
de Nebengeschäfte, termo que pode ser traduzido por "questões secundárias", relegando a elaboração do Estado ético exclusivamente à vontade moral.

Acredito que Jacques Derrida está certo quando sugere que a persistente crítica a Nebengeschäfte - razão calculada no lugar da elaboração moral - deve ser tomada como uma tarefa primária em um mundo multicultural e de múltiplas fés (DERRIDA, 2001). Isso é absolutamente crucial nos dias de hoje. Secularistas puritanos, histéricos ante a mera menção da religião, estão em grande medida desconectados das populações deste mundo e enterraram suas cabeças na areia. A produção de classe lhes permitiu racionalizar e privatizar o transcendental, que passou a ser visto como o telos de boas-vindas para todos, em qualquer parte, sem preparação histórica para essa particular episteme de classe.

À alteridade radical, o outro que a razão precisa mas que não pode apreender, pode ser dados muitos nomes. Deus é, em muitas línguas, o nome mais reconhecível. Alguns lhe denominaram "homem", outros "nação", "natureza", "cultura". A boa fé de Kant se reflete em seu reconhecimento de que a simples razão "precisa" do transcendental. É essa boa fé que permite a mais rigorosa posição de nossa parte, o reconhecimento de uma alteridade radical reiteradamente destranscendentalizada, a fim de coexistir, ainda que descontinuadamente, com a própria fé, sempre vigilante do calculador.

Essas são palavras inoportunas em um mundo de urgências. Mas, os tempos são sempre urgentes e a preparação cultural - agora refletida no ensino das humanidades - é sempre uma tarefa de longo prazo.

\section{3}

0 que falei sobre Kant me levou ao tema do secularismo. A retratação no parágrafo que segue é uma continuação da falta de disposição para a reciclagem que, na minha opinião, havia tomado corpo no Havaí. Nossa sessão na Modern Language Association foi marcada na mesma hora do painel em memória de Edward W. Said, que havia morrido três meses antes. Estava descontente em ter de me ausentar desse painel e me dei conta do quanto meus comentários eram um complemento à obra magistral de Said sobre o crítico secular, que se assemelha ao erudito, o Gelehrte, herói do Iluminismo kantiano, aquele que se "opõe" a todo sistema, que resiste aos sistemas (SAID, 1983; 1994, p. 120). Tive vontade de voltar meu olhar às "pessoas ordinárias". Aqui segue, portanto, o terceiro texto, incluindo sua recalcitrante abertura: 
Esta não é uma polêmica contra o atual estado da guerra. Há outros muito mais capazes do que eu de oferecer uma polêmica informada. Dada a indiferença e a arrogância dos que fazem a guerra, narrar tal polêmica em conferências que não possuem orientação política é de pouco uso. Além disso, não acredito que 0 acúmulo de detalhes sobre o que é obviamente verdadeiro - que a política, quando conveniente, é tão manipulável quanto a religião pelos que fazem a guerra - pode fazer qualquer coisa pelo secularismo. Secularismo não é um estado de espírito, mas uma abstração que deve ser protegida. Não faz sentido adicionar-lhe afeto, à moda das narrativas da "nova matemática". Não. Situados como estamos no universo acadêmico, faz-se necessário repensar tanto a universidade quanto 0 secular.

A universidade está no mundo. E as universidades do mundo são, sem dúvida, estruturadas no "modelo europeu [que], depois de uma rica e complexa história medieval, se estabeleceu [...] ao longo dos últimos dois séculos em Estados do tipo democrático." (DERRIDA, 2002, p. 202). No entanto, essa estrutura não opera em todas as partes com o mesmo grau de eficiência, consentimento informado ou crítica, nem com a mesma qualidade ou relação com o Estado. Ao passo que as melhores universidades nos Estados Unidos pensam cada vez mais em governança mundial, em nome do desenvolvimento sustentável e da globalização ética, bem como em direitos humanos - a fim de se opor à conivência assassina do militar e do econômico -, é justamente no contexto da governança mundial, portanto, que devemos pensar sobre todos os diferentes tipos de universidades, em vez de simplesmente generalizar a partir das universidades que já conhecemos, como se o mundo fosse um só. Se nos detivermos para examinar essa gama de possibilidades, as ideias que veremos circulando entre estudantes e professores serão "identidade cultural", "diferença cultural", "soberania nacional", "políticas de minorias". Mais frequentemente que o esperado, esses tópicos vão se transformando em variedades de liberdade religiosa. Neste ponto me adianto, acrescentando que isso não acontece invariavelmente.

Evidentemente, o lugar histórico e a natureza dos Estados religiosos são importantes. Mas, considerando que uma cultura ativa é a parte menos tangível do comportamento humano, geralmente não éfácil distinguir os signos que exprimem "cultura" a uma coletividade mobilizada dos que podem expressar "religião". Religião, nesse sentido, refere-se aos marcadores ritualísticos de como veneramos e inscrevemos a nós mesmos em relação à diferença sexual. Sem necessidade de "evidência" referencial, são gestos performativos do ser-humano entre o natural 
e o sobrenatural, um lugar precário que requer constantemente essa semiose, que captura e controla a possibilidade do transcendental escrevendo-o como aquilo que é venerado. Vimos que Kant deixa de lado esse nível fundamental de institucionalidade da religião, como se fosse sinônimo de negociações automáticas da cultura, como Nebengeschäfte.

Tal perspectiva do século XVIII ainda persiste naqueles que pregam que "a verdadeira religião foi expropriada para se transformar em algo terrível" ou "alguns poucos maus exemplos estão corrompendo o todo". Não há nada de necessariamente ruim com esses sentimentos. No entanto, se estamos pensando em secularismo devemos aceitar esse grau perene de algo que talvez chamemos religião, mas que poderíamos também chamar de cultura; algo que está sempre pronto para fisgar por se tratar de uma espécie de esfera protopública ou, nas palavras de Said, uma "afiliação-em-filiação" para irmãs e irmãos honoráveis. Aqui não é possível nem desejável ser preciso. Samuel Huntington (1997) está tão equivocado justamente por apresentar uma identificação precisa entre religião e cultura. Em meio a essa imprecisa e imbricada normalidade, não se trata, estritamente falando, de crença, mas de algo similar à competência linguística. Requer-se tal competência, demandando diferentes níveis de negociações semânticas, em diversas situações psicopolíticas. Significações de gênero adquirem aqui um notável papel, com diferentes níveis de aquiescência, incluindo consensos. De fato, pode-se afirmar que a trama das narrativas permissíveis constitui a base da semântica de gênero. 0 preparo para o secularismo é político: trabalhar por um mundo no qual a religião pode ser reduzida a essa mundana normalidade.

A fim de termos um mundo sustentável sobre essas bases, necessitamos do conhecimento ensinado nas humanidades. Estou falando, claro, dos conhecimentos de leitura, de apreensão da diferença fundamental entre registros de linguagem, com a esperança de desenvolver "instrumentos de trabalho" que nos levem ao encontro do mundo em que vivemos, de maneira a tornar possível lermos o exemplo de Martin Luther King Jr. como uma narrativa singular e não verificável, de alguém que amou tanto seus inimigos que morreu por eles. Deve estar claro, a partir da minha descrição do lugar da religião, que o secularismo - o qual definirei a seguir - é uma crítica obstinada; um obstinado instrumento de trabalho que nos ajuda a reconhecer a língua mais enquanto sistema, do que fundamento para a fé. Se pretendemos continuar trabalhando por este mundo, precisamos desfazer parcialmente (apenas parcialmente) o aprendizado dos últimos séculos europeus e refazer maciçamente o programa das histórias que 
foram privadas do direito à representação. Posto dessa forma, parece bastante assustador. Mas não precisa ser assim se pensamos nisso como um projeto coletivo a ser realizado na sala de aula.

Se muitas vezes não se pode distinguir os signos que exprimem "cultura" a uma coletividade dos que facilmente exprimem "religião", o mesmo também ocorre com a "cultura" que fetichiza a simples razão [reasonableness]. No seu modo mais sublime, Kant mostra isso em "A Religião nos Limites da Simples Razão". Já havia falado sobre esse texto e, agora, devotarei mais algumas linhas a ele.

Apesar de ter feito uma tentativa de mostrar que todas as religiões tendem a dramatizar o papel que a razão deve assumir, a fim de garantir uma coletividade ética, não resta dúvidas de que Kant tinha em mente o cristianismo como "a primeira igreja verdadeira" (KANT, 1996b, p. 181).

Tal convenção, de que $a$ religião secular é a judaico-cristã, constitui um pré-juízo que ainda nos orienta e que só se legitima pelo seu reverso, como na obra de Sayyid Qutb sobre o Islã. Se a religião judaico-cristã é vista como a religião da razão, destranscendentalizada em secularismo, é também a descrição da captura e do controle da possibilidade do transcendental como aquilo que é venerado, o que caracteriza a religião-enquanto-cultura, conforme visto anteriormente.

Meu argumento é que, independente de seu posicionamento político ou de sua religião, o lugar da razão em qualquer forma de secularismo permanece implacável. Se a razão deve ser nossa aliada - considerando que não podemos abrir mão dela -, então não pode ser fetichizada, como na versão mais corrente de secularismo, a saber, um cristianismo judaico de cara nova. A versão atual mais amena - "ensinar a tolerância" - é, claro, uma coisa boa. Mas, como já demonstraram os reais esforços de Kant há dois séculos em relação à tolerância no fim de "A Religião nos Limites da Simples Razão", a tolerância nos permite destranscendentalizar todas as outras religiões menos a linguagem religiosocultural que rege nosso próprio idioma. Basicamente, esse é o mesmo problema do relativismo cultural. Tolerância, virtude tão fácil na teoria, é difícil na prática. No melhor dos casos, trata-se de uma virtude privada. Um Estado "tolerante" é um Estado secular. Estamos falando do âmbito jurídico-legal, não do psicológico. Ele tem maiores condições de florescer quando a religião é destranscendentalizada em algo similar à competência linguística, o que é mais fácil de acontecer quando não há necessidade de mobilizar - e não quando ocorre sua privatização por uma determinada classe. 
Em outras palavras, torna-se evidente que dois legados que nos foram deixados pelo século XVIII europeu - a separação entre igreja e Estado e a separação entre o público e o privado - são demasiadamente marcados por especificidades tanto de raça e classe quanto de gênero para que possam ser capazes de sustentar um mundo justo. A privatização do transcendental funciona apenas para um punhado de pessoas. Nosso mundo nos mostra que o secularismo não é uma episteme. É uma fé na razão em si e por si mesma, protegida por estruturas abstratas externas - 0 arranjo mais frágil possível para refletir a condição humana. Sob essas circunstâncias, convido você a pensar o secularismo como uma prática ativa e obstinada - uma responsabilidade -, a fim de manter as estruturas da ação [agency] livres de crença e fé. 0 secularismo é rarefeito, muito pobre existencialmente para adquirir a substância de uma linguagem ou de uma "identidade". É um mecanismo frágil, que serve para se evitar a violência e que deve ser aprendido como simples razão [reasonableness].

Que papel podemos desempenhar na promoção da prática do secularismo em vez de simplesmente "sermos seculares"? Pense no papel que a crença religiosa passou de fato a desempenhar nas universidades contemporâneas multiculturais e você verá que "ser secular" é, geralmente, uma questão de preservar o próprio secularismo. 0 que vou sugerir agora não corrobora a ideia de que existe um espírito iluminista secular para o qual devemos iniciar novos ritos de conversão, senão que devemos reconhecer que o secularismo se mantém sempre apenas como possibilidade, e que um extenuante esforço é necessário para protegê-lo enquanto tal. Nenhuma religião tem acesso privilegiado a ele.

(Durante a Convenção Anual da Associação de Línguas Modernas, tive a sorte de receber muitos retornos a esse respeito. Um dos mais importantes veio de meu velho amigo Phil Lewis, que comentou ser esta minha mais importante contribuição para pensar uma prática secular abrangente: que o secularismo permanece sempre "como uma possibilidade". "Mas", disse Phil, "vai ser difícil para as pessoas entenderem, Gayatri". Acredito que o exercício que é requerido agora procura justamente este entendimento: que o secularismo é um conjunto de leis racionais abstratas que devem ser observadas a fim de se evitar a violência religiosa).

Neste ponto, deve estar claro que qualquer declaração sobre o suposto "universalismo" de um secularismo fundamentado na razão é para mim suspeito, porque esconde o fato de que declarações dessa natureza estão embasadas não só na ideia de que a universidade - lugar destinado ao exercício de profundas 
mudanças subjetivas - é uma instituição de mobilidade de classes, mas também, especificamente, uma instituição de mobilidade de classes no estilo europeu. No entanto, por mais europeu que seja o modelo da universidade moderna, nosso compromisso com o multiculturalismo resiste a tal cenário. Até mesmo a descrição do fórum realizado na Associação de Línguas Modernas reflete esse objetivo de apresentar "visões da universidade contemporânea que vão além do eixo EuropaAmérica do Norte". É justamente a imagem do "intelectual secular universal" que já não se adequa ao que a universidade precisa hoje produzir.

Com o objetivo de pensar em uma alternativa, retorno a Kant, o filósofo que melhor definiu o intelectual secular universal que deveria ser produto da universidade: iluminado é o erudito que escreve para todos os tempos e lugares. Para alguns indivíduos da nossa geração, isso ainda corresponde a um nobre ideal - e é justamente aí que situei as considerações de Said sobre o criticismo secular.

A maravilhosa declaração de Kant sobre publicidade nos exorta a sermos obedientes a um trabalho em que esperaríamos um testemunho de liberdades públicas. Se olharmos para os escritos filosóficos de Kant, especialmente "A Religião nos Limites da Simples Razão", escrita no fim de sua vida, veremos que a ideia kantiana de vida ética comum - no original, gemeines Wesen, cuja tradução "esfera pública" deixa muito a desejar - não é baseada na separação entre o público e o privado, mas no fato de que todos os seres humanos têm a mesma razão e, portanto, que o objetivo da humanidade é coletivo. (A igreja, que é uma instituição pública, também se confunde com o privado.) Como tentei argumentar, é sobre a universalidade da razão que também se sustenta a promessa do secularismo. Como Kant tinha profunda consciência dos limites da razão, perguntou a si mesmo se seria possível criar algo que também poderíamos chamar de secularismo - um que incorporasse intuições do transcendental. Vejamos como Kant resolveu esse problema e o que nós - que devemos ser justos à nossa dívida para com seu pensamento e, ainda assim, contradizê-lo quando necessário podemos aprender com ele.

Para começar, ainda que a razão seja una - e, de fato, o fundamento da ética comum -, Kant fratura essa unidade mais do que nós mesmos somos capazes de fazê-lo ao depositar uma fé cega no secularismo, tal qual o entendemos. (0 próprio Kant sempre afirmou que as diversas razões constituíam diferentes formas de manifestação de uma mesma razão. Isso deve ser tomado como pressuposto para o que será aqui argumentado.) Entre as fraturadas funções da razão, Kant estabelece uma relação assimétrica. A razão pura, sobre a qual Kant tem 
maiores suspeitas, é a mais elevada função da razão. E a razão simples, com a qual operamos no dia a dia e que é apenas confiável [accountable] - mais zurechnungsfähig que responsável [responsible] - é inimiga do trabalho moral. Dessa maneira, ao descrever como deveríamos filosofar a moral na razão pura, Kant nos pede, literalmente, para abrirmos espaço - einräumen - aos efeitos da graça.

Isso soa muito eurocêntrico e, como tal, me ajudará a questionar a leitura de Kant que é usada para justificar a governança global2 ${ }^{22}$. Há certo grau de autoconfiança nessas justificativas, enquanto a implacável honestidade de Kant o leva a conter a razão.

$\mathrm{Na}$ instituição espacial da razão pura, então, devemos abrir espaço aos "efeitos da graça". Na última seção desta última "crítica", em que Kant fala de governança mundial, com reiteradas referências teológicas (já que está combatendo a faculdade teológica), ele insiste que uma instituição global baseada na existência comunal ética é impossível. 0 ético não pode ser institucionalizado de imediato.

Aprendi minhas formas de ler o passado com Marx e, aqui, pretendo ler Kant como Marx leu Aristóteles, com admiração, mas também com o reconhecimento histórico de que ele não poderia ter imaginado a forma-valor [Werfform]. Mesmo dentro de seu brilhante modelo da unidade fraturada da razão, Kant falou do "efeito da graça" porque não podia imaginar uma universidade nos moldes europeus em que a faculdade de teologia não fosse dominante. Temos de adotar a força revolucionária da palavra "efeito", livrá-la do teológico e passá-la ao estético. "Efeito" é o mais próximo que Kant pôde chegar da graça destranscendentalizada. A graça é apreendida tal qual a figura da metalepse - 0 efeito de um efeito. Considerando que a razão pura - ou, de fato, qualquer tipo de razão - não pode conhecer a causa, tudo o que é inscrito é um efeito.

Hannah Arendt (1990) falou sobre o potencial político do juízo reflexionante estético kantiano. 0 que proponho se relaciona com essa ideia. A maioria de nós está familiarizada com a tradução, um pouco descompassada, do conceito estética utilizado na língua inglesa: um propósito sem propósito. Sabemos que Kant nos

\footnotetext{
${ }^{22}$ Seria preciso espaço e tempo muito mais amplos para fundamentar esse argumento adequadamente. Considerando tal falta, faço pelo menos referência à parte final do documento assinado por Jacques Derrida e Jürgen Habermas no jornal Frankfurter Allgemeine de 31 de maio de 2002. A posição de Derrida em relação a Kant é, de todas as maneiras, muito mais refinada, como evidenciam seus muitos escritos sobre Kant,ao longo de sua carreira.
} 
diz que a estética confere prática à faculdade de poder representar sem conceitos objetivos. Então, sempre ponderando e verificando as diferentes posições, Kant, na terceira crítica, segura a tendência da imaginação de ir longe demais, ao enfatizar antes a tarefa do entendimento que a da razão.

Em "A Religião nos Limites da Simples Razão", implicitamente - e, em grande medida, sem se dar conta - Kant desloca a tarefa de representar sem conceitos - a figuração - para a figuração da graça enquanto quase-metalepse o não verificável efeito de um efeito - que, por sua vez, é deslocada para questões secundárias ou trabalho externo à razão pura. Agora o entendimento já não é mais um obstáculo à imaginação, como na terceira crítica. A figuração passa a complementar a mera indolência moral calculada da razão.

Perdoem-mepelo caráter abstruso doúltimo parágrafo. 0 multiculturalismo universalista teria sido mais palatável aqui. Espero que a paciência do leitor me conceda ainda algumas linhas.

Em apoio à minha interpretação, ofereço o fato de que "A Religião nos Limites da Simples Razão" é uma extensão alegórica ou uma leitura deturpada do Novo Testamento - uma espécie de teologia da libertação. Farei agora uma sugestão que, espero, não lhe vá causar espanto. Voltemos ao tema do atentado suicida.

A teologia da libertação funciona porque traduz ao pé da letra a metaforologia da cultura religiosa. 0 atentado suicida opera da mesma maneira. Não estou equiparando - e muito menos defendendo - os dois. A única coisa que têm em comum é uma má política de gênero. Nos últimos anos, tenho procurado imaginar o atentado suicida porque estou convencida de que rejeitá-lo enquanto evento patológico, assassino ou uma aberração é falar a partir daquelas posturas que já foram discutidas. Você já escutou falar de mães palestinas que lamentam a transformação de seus filhos e filhas em terroristas suicidas na atual conjuntura? Era disso que falava no começo do texto, quando mencionei que o sempre acessível bilinguismo entre religião e cultura, enquanto idioma, pode ser ativado em determinadas situações. Se a teologia da libertação mobiliza fazendo uso de metáforas ao pé da letra, no caso do atentado suicida observamos a recodificação das narrativas religiosas como referencial no sentido mais estrito.

Todavia, a formação nas humanidades não realiza nenhum desses dois movimentos - antes, nos ensina a aprender daquilo que é singular e não verificável. A universidade, para se tornar secular, requer um esforço epistêmico sustentável que só pode vir das humanidades. A ideia de que o secularismo 
pode ser mantido tão somente pela formação em ciência política e em direito faz parte das formações disciplinares privadas, nas quais o controle do sujeito costuma permanecer inquestionado. São as humanidades que podem oferecer a instrução prática contínua de destranscendentalização do radicalmente outro - re-inventando graça como uma necessária metalepse -, uma lição aprendida através da subversão do profeta do modelo anterior ${ }^{23}$. As humanidades devem aprender a des-trivializar a si mesmas e tomar o lugar que lhes é devido na universidade, em meio a este turbulento século. Estou absolutamente chocada em ver jovens e conservadores colegas insistirem, com surpreendente estreiteza, em ensinar "apenas conhecimentos literários", alegando que seus estudantes chegam despreparados, enquanto o mundo está ruindo ao redor.

Se queremos enfrentar os desafios do século XXI, também temos de aprender línguas. A simplificada leitura que ofereci de Kant não seria possível, mesmo contando com a melhor tradução possível para o inglês ou qualquer outra língua. E não seria preciso buscar as vicissitudes da tradução da palavra "secular" em Estados e sociedades no "resto do mundo".

Não. A tarefa é encontrar algo como o binário "secular/transcendental" nas muitas línguas do mundo, em vez de oferecer traduções abstrusas do inglês ou de palavras metropolitanas. Din aur dunya e jagatik o pamarthik são as duas principais religiões da Índia, com as que trabalho como candidatas à desconstrução [undoing]. De fato, cheguei à definição de religião enquanto marcadores ritualísticos de como veneramos - ki korey thakur pujo kara boy - quando falava com uma camponesa em Bengala Ocidental, no dia 16 de dezembro, uma professora descalça que era completamente incapaz de explicar os ensinamentos religiosos escritos em um livro de educação elementar.

Termino como comecei, exercitando minha atestada qualificação institucional enquanto professora de narrativas. Abro Baby No-Eyes, romance da escritora maori Patricia Grace (1998, p. 293). Minha amiga e colega Carolyn Sinavaiana me ajudou a dar aulas sobre esse livro e me ofereceu um impressionante

\footnotetext{
${ }^{23}$ Derrida alertou em "Différance" que um efeito sem a causa levaria a uma primeira causa. A quase-metalepse kantiana da graça ainda contém Deus em seu limite, embora Kant seja cuidadoso em assegurar isso enquanto possibilidade de todas as maneiras, sendo uma das mais importantes a discussão sobre o uso hipotético da razão (KANT, 1998, p. 590-604). 0 argumento de Derrida refere-se a que localizar o efeito da graça em textos não necessariamente invocaria uma causa sem causa (DERRIDA, 1982, p. 17). Dito de outra forma, trata-se da destranscendentalização do radicalmente outro, a causa sem causa, o esforço persistente de uma formação em humanidades.
} 
retrato da visão de mundo maori, que reconhece - no lugar da distinção entre 0 público e o privado - a circulação e o compartilhamento entre todos os membros. Havia mencionado anteriormente a noção kantiana de vida ética comum e de unidade da razão. Como argumentei alguns anos atrás em relação à revisão do Iluminismo, feita por Buchi Emecheta, essas características do pensamento kantiano permitem que ele possa ser expandido para além de sua procedência europeia (SPIVAK, 2004). Mas, o que ainda gostaria de colocar é que o último capítulo do romance termina em uma universidade em que o mais novo maori aprende a "tentar o oposto", a lição mais sucinta da imaginação que se afasta da identidade como referência. Se Beloved, de Toni Morrison, é um romance sobre o deslocamento da África para a Afroamérica, Baby No-Eyes marca o início do deslocamento de Aotearoa para a Nova Zelândia. É sobre tais mudanças históricas que a obstinada tarefa de manter a universidade secular - através da obstinada des-transcendentalização do radicalmente outro, em um espaço de efeito, e do obstinado reconhecimento da religião/cultura como idioma e não como fundamento de crenças - está entregue nas mãos da pedagogia e das disciplinas das humanidades.

\section{REFERÊNCIAS}

ABD AL-RĀHMĀN KHĀN, Amir of Afghanistan, d. 1901. The life of Abdur Rahman, Amir of Afghanistan. Karachi: Oxford University Press, 1980.

ARENDT, Hannah. Lectures on Kant's political philosophy. Chicago: University of Chicago Press, 1990.

BENJAMIN, Walter. Critique of violence. In: Reflections: essays, aphorisms, autobiographical writing. Nova York: Schocken, 1978.

CASTLE, Terry. Courage, mon amie. London: Review of Books, 2002.

CHAUDHURI, Kirti N. Asia Before Europe: Economy and Civilization of the Indian Ocean from the Rise of Islam to 1750. Nova York: Cambridge University Press, 1990.

CHOMSKY, Noam. 9-11. Nova York: Seven Stories Press, 2001.

CHOMSKY, Noam. The theatre of good and evil. Disponível em: <http://www.zmag. org/chomskygsf.htm>. Acesso em: s/d

CROSSETTE, Barbara. How to put a nation back together again. The New York Times, New York, Week in Review Section, 25 november 2001, p. 3.

DAVIS, Mike. Dead cities, and other tales. Nova York: New Press, 2002. 
DERRIDA, Jacques. Différance. In: - Margins of philosophy. Chicago: University of Chicago Press, 1982.

. Faith and knowledge. In: ANIDJAR, Gil (Ed.). Acts of religion. Nova York: Routledge, 2001. p. 42-101. .The University without condition. In: Without Alibi. Stanford: Stanford University Press, 2002. . Voyous. Paris: Galilée, 2003.

DEVI, Mahasweta. Douloti the bountiful. In: Imaginary maps. Nova York: Routledge, 1995.

EATON, Richard M. Temple desecration in pre-modern India. Frontline, India, v. 17, n. 25, p. 62-70, dez. 2000.

FLETCHER, George P. Romantics at war: glory and guilt in the age of terrorism. Princeton: Princeton University Press, 2002.

GRACE, Patricia. Baby no-eyes. Honolulu: University of Hawaii Press, 1998.

HARDT, Michael; NEGRI, Antonio. Empire. Cambridge: Harvard University Press, 2000.

HUNTINGTON, Samuel P. Clash of civilizations and the remaking of world order. Nova York: Touchstone, 1997.

KANT, Immanuel. What Is Enlightenment? In: SCHMIDT, James (Ed.). What is enlightenment? eighteenth-century answers and twentieth-century questions. Berkeley: University of California Press, 1996a. p. 58-64.

. Religion within the boundaries of mere reasonin. In: GUYER, Paul (Ed.). Religion and rational theology. Cambridge: Cambridge University Press, 1996b. . Critique of pure reason. Cambridge: Cambridge University Press, 1998. . Critique of the power of judgement. Cambridge: Cambridge University Press, 2000.

LACAN, Jacques. The splendor of antigone. In: The ethics of psychoanalysis 1959-1960: seminar book VII. Nova York: Routledge, 1992.

LEWIS, Martin W.; WIGEN, Karen E. The myth of continents: a critique of metageography. Berkeley: University of California Press, 1997.

LIPTON, Eric; GLANZ, James. A nation challenged: relics; from the rubble, artifacts of anguish. New York Times, New York, Seção 1, 27 Jan. 2002. 
MANDER, Harsh. Cry, the beloved country: reflections on the gujurat massacre. 2002. Disponível em: <http://www.sabrang.com/gujarat/statement/nv2.htm>. Acesso em: s/d

MARWAT, Fazal-ur-Rahim. The evolution and growth of communism in Afghanistan (1917-1979): an appraisal. Karachi: Royal Book, 1997.

MASSELL, Gregory J. The surrogateproletariat: moslem women and revolutionary strategies in soviet central Asia, 1919-1929. Princeton: Princeton University Press, 1974.

MUJTABA ALI, Syed. Works. Kolkata: Mitra and Ghosh Publishers, 1974. v. 7.

OSORIO, Jon Kamakawiwo'ole. Dismembering Labui: the history of the hawaiian nation until 1887. Honolulu: University of Hawaii Press, 2002.

PRASHAD, Vijay. War against the planet: the fifth afghan war, imperialism, and other assorted fundamentalisms. Nova Délhi: LeftWord, 2002.

SAID, Edward W. Secular criticism. In: The world, the text, and the critic. Cambridge: Harvard University Press, 1983. p. 1-30. . Gods that always fail. In: . Representations of the intelectual. Nova York: Columbia University Press, 1994.

SHELLEY, Percy Bysshe. The defense of poetry. In: McELDERRY, Bruce R. (Ed.). Shelley's critical prose. Lincoln: University of Nebraska Press, 1967.

SLAUGHTER, Anne-Marie. Tougher than terror. The American Prospect, Estados Unidos, 28 January 2002.

SPIVAK, Gayatri Chakravorty. Can the Subaltern Speak? In: NELSON, Cary; GROSSBERG, Larry (Ed.). Marxism and the interpretation of culture. Urbana: University of Illinois Press, 1988. p. 271-313.

. A critique of postcolonial reason: toward a history of the vanishing present. Cambridge: Harvard University Press, 1999. n. 32. p. 26-29.

What is enlightenment? Gayatri Chakravorty Spivak conversing with Jane Gallop. In: GALLOP, Jane (Ed.). Polemic: critical or uncritical. Nova York: Routledge, 2004. p. 179-200.

. Other Asias. Oxford: Blackwell, 2008.

STOCKHAUSEN, Karlheinz. Attacks called great art. The New York Times, New York, 19 Sep. 2001. p. 3.

WORLD BANK. Creating cities that work in the new global economy. Research Bulletin, v. 10, n. 4, Oct./Dec. 1999. p. 1. 